\title{
Kilka uwag o konstruktywistycznym poznawaniu tekstu dawnego: De perfecta poesi Macieja Kazimierza Sarbiewskiego
}

DOI: http://dx.doi.org/10.12775/LC.2016.041

Streszczenie. Celem artykułu jest naświetlenie problemów konstruktywistycznego poznawania tekstu dawnego na przykładzie interpretacji traktatu De perfecta poesi M. K. Sarbiewskiego. Autor tekstu wyjaśnia w nim charakterystykę obcowania z dziełem dawnym, przedstawiając proces badania literatury dawnej w świetle postulatów konstruktywistycznej koncepcji poznania. Poznawanie tekstu dawnego jawi się w tej optyce jako zdeterminowane stylem badawczym, procesualne i otwarte, świadome narracyjności procesu badawczego, a także jego wieloetapowości i złożoności.

Słowa kluczowe: konstruktywizm, epistemologia, tekst, literatura, poetyka

Abstract: The purpose of this article is to present problems of constructivist knowledge of the literary text. The author explains the characteristics of the work with old text and presented the process of studying ancient literature in perspective of the constructivist conception of knowledge. The research process is the vision of a socially conditioned, complex and open. constructivism, epistemology, text, literature, poetics

* Historyk i teoretyk literatury. Zajmuje się poetyką dawną, retoryką i teorią historiografii. Przygotowuje pracę doktorską poświęconą wpływowi renesansowego systemu genologicznego na reprezentację historii Wielkiego Księstwa Litewskiego w epice Macieja Stryjkowskiego. E-mail: ukaszlipinski@gmail.com. 
prezentowanym artykule podejmuję próbę opisania niektórych aspektów konstruktywistycznego poznawania tekstu dawnego. Temat wypowiedzi zobowiązuje mnie więc do zadania pytania, jakie to jest konstruktywistyczne poznawanie i czym jest tekst dawny jako obiekt poznania konstruktywistycznego? Zanim jednak odpowiedź ta stanie się możliwa, pragnę przedstawić specyfikę przedmiotu tych rozważań, w których skupiam uwagę na siedemnastowiecznym traktacie poezjoznawczym De perfecta poesi, sive Vergilius et Homerus (ukończ. ok. roku 1626). Jego autorem jest polski profesor retoryki i poetyki Maciej Kazimierz Sarbiewski ${ }^{1}$. Od jakiegoś czasu zajmuję się interpretacją jego rozprawy na temat poezji epickiej, czyniąc to przy pomocy instrumentarium pojęciowego współczesnej teorii literatury spod znaku strukturalizmu - głównie narratologii francuskiej.

Ktoś mógłby zatem zadać sceptyczne wobec mojego projektu pytanie: dlaczego staram się wyjaśnić tekst dawny poprzez kontekst współczesny? Czy poznawanie artefaktu piśmiennictwa zrodzonego w łonie kultury staropolskiej nie powinno wiązać się przede wszystkim z próbą dotarcia do jego sensu historycznego, powiązanego z kontekstem macierzystym, w którym ten tekst powstał? ${ }^{2}$

Specyfika merytoryczna traktatu Sarbiewskiego uniemożliwia jednak przedstawienie jednoznacznej odpowiedzi na tak postawione pytanie. W przypadku traktatu De perfecta poesi badacz nie musi bowiem ograniczać się do prób odtworzenia relacji dzieła z jego lokalnym systemem literackim i kulturą literacką (renesansowym arystotelizmem oraz horacjanizmem), lecz może dokonać swoistej syntezy owej optyki historyczno-archiwalnej z perspektywą na pierwszy rzut oka „ahistoryczną", ujmującą wybrane aspekty rozprawy Sarbiewskiego w ich relacjach z innymi, tj. współczesnymi pracami teoretycznoliterackimi. Nie ulega zarazem wątpliwości, że odczytawszy Arystotelesowskie dzieło Sarbiewskiego

1 M. K. Sarbiewski, De perfecta poesi, sive Vergilius et Homerus (O poezji doskonałej, czyli Wergiliusz i Homer), przeł. M. Plezia, oprac. S. Skimina, Wrocław 1954.

2 Powinno się zatem zwrócić uwagę na dyskusję, w której biorą udział badacze skupieni przede wszystkim wokół toruńskiej szkoły historii literatury staropolskiej, a także badacze argumentujący zasadność jedynie tradycyjnych metod historycznoliterackich. Literaturoznawcy z pierwszej strony dyskusji podejmują próby reinterpretacji tekstów dawnych przy pomocy pojęć humanistyki współczesnej, które to działania wpisują się, m.in., w projekt postulowany przez Teresę Walas w książce Czy jest możliwa inna historia literatury?, Kraków 1993. Autorka proponuje w niej możliwość otworzenia się literatury dawnej na różne, również niejako ahistoryczne względem niej dyskursy. Wśród aktualnych publikacji, które są śladami wspomnianej dyskusji, należy wymienić, m.in., artykuły Pawła Bohuszewicza Po co literaturze dawnej współczesna teoria?, "Litteraria Copernicana” 2008, z. 2, red. K. Obremski; idem, Zwiqzki niebezpieczne, zwiqzzi konieczne. O "alternatywnych" sposobach lektury tekstów staropolskich „„Roczniki Humanistyczne” 2011, t. LIX, z. 1; idem, Nowożytność, kontekst, pedokomparator, czyli o trzech sposobach na wyjście z getta (na marginesie artykułu Iwony Maciejewskiej), „Prace Literaturoznawcze” 2015, nr 3. Natomiast wśród zwolenników metod tradycyjnych przede wszystkim artykuły A. Nowickiej-Jeżowej, Komparatystyka i filologia. Uwagi o studiach porównawczych literatury epok dawnych, [w:] Polonistyka w przebudowie. Literaturoznawstwo - wiedza o języku - wiedza o kulturze - edukacja. Zjazd polonistów Kraków 22-25 września 2004, t. 2, red. M. Czermińska et al., Kraków 2005, a także A. Czechowicz, Uwagi o przymusach metodologicznych w badaniach literatury staropolskiej, ,Roczniki Humanistyczne” 2008, z. 1; eadem, Glosa do metodologii przyczynków, czyli po co nam to wszystko, "Roczniki Humanistyczne” 2011, z. 1; oraz T. Nastulczyka, P. Oczki, „Tradycyjni” czy "nowocześni"? O metodologicznych dylematach współczesnych badaczy staropolszczyzny, "Terminus" 2013, t. 15, z. 3. W artykule tym jednym z zarzutów przeciwko badaczom stosującym nowoczesne słowniki do opisu dzieł dawnych stał się ich rzekomy błąd ahistoryzmu. Pragnę jednakże podkreślić - co poniekąd dowodzi moja praca magisterska, a także przywołany w poniższym przypisie artykuł - że perspektywa nowoczesno-metodologiczna nie musi wykluczać możliwości zajęcia perspektywy historycznej, a więc umieszczania dzieła w jego kontekście macierzystym. 
O poezji doskonałej za pomocą kategorii pojęciowych współczesnych teorii narracji ${ }^{3}$, narażałem się na zarzut ahistoryczności wywodu; zwłaszcza wśród zwolenników historyzmu w badaniach literackich. Sarbiewski ze względu na ponad trzystuletnią różnicę czasową nie mógł bowiem znać nowoczesnej myśli strukturalnej, natomiast strukturaliści francuscy bez wątpienia częściej czytywali pisma de Saussure’a, Proppa, Chomsky’ego czy Lévi-Straussa, niż rozprawy Arystotelesa, Diomedesa, Cycerona i Kwintyliana, które były z kolei tak bliskie teoretycznej wyobraźni siedemnastowiecznego, jezuickiego preceptora poezji. Tak czy inaczej, twórcy narratologii strukturalistycznej, podobnie jak Sarbiewski, przyswoili koncepcję poezji jako ogólnych i uniwersalnych zasad ponadgatunkowych (oczywiście w formie przetworzonej przez wieki długiego trwania tradycji intertekstualnej) i wynikające z niej założenia metodologiczne, adaptując je następnie na grunt analizy strukturalnej opowiadania. Należy przy tej okazji przypomnieć, że Roland Barthes podkreśla we Wstępie do analizy strukturalnej opowiadań, iż koncepcja ogólności i ponadgatunkowości struktur narracyjnych jest bezpośredniej proweniencji Arystotelesowskiej ${ }^{4}$. Wypada zarazem pamiętać, że zarówno Sarbiewski, jak i strukturaliści partycypowali w ramach podobnego zestawu wyobrażeń na temat przedmiotów estetycznych (w tym literatury), który już w starożytności stał się zaczynem dla usytuowanych lokalnie i historycznie poetologicznych wspólnot interpretacyjnych. Nie bez znaczenia dla wspólnoty wyobrażeń metodologicznych na temat poezji pozostają tutaj słowa jednego z klasyków myśli nowoczesnej filozofii:

Podobieństwo rodzinne wszelkiego filozofowania indyjskiego, greckiego, niemieckiego dość prosto się tłumaczy. Tam właśnie, gdzie istnieje powinowactwo językowe, wprost uniknąć niepodobna, by dzięki wspólnej filozofii gramatyki - mniemam, dzięki nieświadomemu władaniu i kierownictwu jednakich funkcyj gramatycznych - nie było wszak przygotowane z góry do jednakowego rozwoju oraz następstwa systemów filozoficznychs .

Prefiguracji strukturalnego stylu myślowego w refleksji nad poezją należy upatrywać w długim trwaniu łacińskiej tradycji grecko-rzymskiej metafizyki obecności i logocentryzmu, utrwalającej na przestrzeni wieków przekonania o eksplanacyjnej mocy słowa i absolutnej obecności sensu, który - jako byt dany uprzednio - miał się skrywać w porządku znaków języka, czekając na odkrycie w czasie intersubiektywnej interpretacji. Jeśli do powyższej charakterystyki teoriopoznawczej dołączy się kryterium uniwersalizmu dyskursu naukowego, skupianie się w rozważaniach o sztuce słowa na tym, co w niej ogólne i zarazem wspólne dla wielu z pozoru różnych utworów - w przypadku De perfecta poesi na sformalizowanych procedurach wynajdywania fabuly epickiej, natomiast w pracach narratologii strukturalistycznej na ogólnych warunkach wytwarzania sensu, w tym sensu literackiego - to wbrew wcześniejszym pozorom ahistoryczności można się zorientować, że Arystotelesowska koncepcja poezji jest bardzo strukturalistyczna, stanowiąc podglebie metodologiczne zarówno dla Sarbiewskiego, jak i dla narratologów francuskich (i nie tylko).

\footnotetext{
3 Ł. Lipiński, „De perfecta poesi” Macieja Kazimierza Sarbiewskiego w perspektywie współczesnych teorii narracji, „Meluzyna" 2014, nr 1.

4 R. Barthes, Wstęp do analizy strukturalnej opowiadań, przeł. W. Błońska, „Pamiętnik Literacki” 1968, z. 4, S. 328-330.

5 F. Nietzsche, Poza dobrem i złem, przeł. S. Wyrzykowski, Warszawa 2015, s. 26.
} 
Pomimo tego optymizmu poznawczego należy jednak pamiętać, że literaturoznawstwo jest poszukiwaniem i opisywaniem nie tylko tego, co tożsame, lecz również tego, co różne. I umiejętnością nadawania owym różnicom odpowiedniej instancji ważności ze względu na należący się im szacunek za to, że zostały one w taki czy inny sposób przekazane do czasów obecnych. Trudno więc nie zgodzić się z Mortonem H. Bloomfieldem, gdy pisze on, że „badania literackie dążą do nadania minionej literaturze doniosłości, dzięki ustalaniu bądź pierwotnej jej wymowy, bądź wymowy współczesnej”. Jacques Derrida nie bez powodu zadaje w Sile i znaczeniu istotne w tej perspektywie pytanie, dlaczego używamy dzisiaj słowa „struktura”, a nie np. podobnych znaczeniowo słów w rodzaju „forma” albo eidos? Otóż musimy pojąć - twierdzi autor O gramatologii - dlaczego terminy te okazują się współcześnie niewystarczające, ale też z jakiego powodu pojęcie „struktura” cały czas zapożycza od nich pewne implicytne znaczenie i udziela im gościny ${ }^{7}$. Derrida wskazuje przyczynę występowania owej „pasji strukturalistycznej”, w której barokowość (a zatem kontekst historyczny epoki Sarbiewskiego) „byłaby jednym tylko tego przykładem; czyż nie mówiono w związku z nią o poetyce strukturalnej i retorycznej bazie”? - pyta Derrida ${ }^{8}$. Problemy inwencji fabuły epickiej oraz narratologiczne warunki strukturyzowania sensu krążą zatem w zasadniczo różnych wymiarach historycznych i lokalno-kulturowych, lecz nadal niejako po tym samym torze myślowym. Biorąc pod uwagę długie trwanie tradycji intelektualnej, należy pamiętać, że wiele tendencji w refleksji poetologicznej bierze swój początek w różnych przekształceniach logocentrycznej tradycji grecko-rzymskiej, która jest wiekowym kontekstem macierzystym tak dla literatury, jak dla jej teorii. Jaki jest zatem praktyczny cel takiego odczytania? Moim zdaniem jeden - a mianowicie pokazanie, że literatura staropolska może oddychać atrakcyjnym dla młodych badaczy powietrzem współczesnego dyskursu literaturoznawczego, niemniej w przypadku De perfecta poesi Sarbiewskiego i prac narratologów nie są to zbieżności wyszukane „na siłę”, lecz będące rezultatem skrupulatnych analiz tekstualnych i kontekstowych.

Wychwycenie powinowactw między teoriami Sarbiewskiego i narratologów było osiągalne w ramach określonej wspólnoty badaczy, posługujących się tożsamym stylem myślowym 9 . Zanim możliwe stało się dojście do wniosków o transferze myśli strukturalnej między genetycznie niepowiązanymi ze sobą tekstami teoretycznoliterackimi, stanowiłem jako badacz część pewnej grupy akademickiej, której członkowie podzielali określone przekonania co do obchodzenia się z tekstami staropolskimi. Dobre warunki komunikacyjne panujące w ramach tej wspólnoty umożliwiły przedyskutowanie tego problemu z wykładowcami, co z kolei w pewien sposób zdeterminowało mój punkt widzenia w oglądzie interesującego mnie tekstu. W perspektywie konstruktywistycznego poznawania artefaktu piśmiennictwa dawnego istotne zdaje się więc twierdzenie, że właściwa rama modalna wypowiedzi badacza literatury-konstruktywisty polega na zdaniu sobie sprawy z faktu, iż przedmiot jego badań jawi mu się ,jako coś”, innymi słowy: jawi mu się w taki właśnie, a nie w inny sposób ${ }^{10}$. To zatem, że przeczytałem i zinterpretowałem traktat De perfecta poesi Sarbiewskiego jako

6 M. H. Bloomfield, Alegoria jako interpretacja, przeł. Z. Łapiński, „Pamiętnik Literacki” 1975, z. 3, s. 219.

7 J. Derrida, Siła i znaczenie, [w:] Pismo i różnica, przeł. K. Kłosiński, Warszawa 2004, s. 9-13.

8 Ibidem.

9 L. Fleck, O obserwacji naukowej i postrzeganiu w ogóle, [w:] idem, Style myślenia i fakty, Warszawa 2007, s. $120-121$.

10 A. Skrendo, Tożsamość w perspektywie konstruktywizmu, „Teksty Drugie” 2004, nr 1/2, s. 67-68. 
traktat narratologiczny, ukonstytuowane zostało do pewnego stopnia przez styl myślowy pracowników Zakładu Literatury Staropolskiej Uniwersytetu Mikołaja Kopernika, interesujących się teorią literatury, co z pewnością nie pozostaje bez wpływu na optykę interpretacyjną, jaką praktykują oni w pracy naukowej i dydaktycznej. Jak bowiem twierdzi Ludwik Fleck, „styl myślowy jest wynikiem teoretycznego i praktycznego wykształcenia danego osobnika, a przechodząc z nauczyciela na ucznia, stanowi pewną wartość tradycyjną podlegającą swoistemu rozwojowi historycznemu i swoistym prawom socjologicznym"11. Każda interpretacja (jako wynik gry ze znaczeniami tekstu) powstaje bowiem zawsze w ramach pewnej wspólnoty, która (dzięki tożsamym przekonaniom i zainteresowaniom grupy badaczy) akceptuje takie, a nie inne sposoby odczytywania tekstów. Właściwa problematyka konstruktywistycznego poznawania tekstu dawnego zaczyna się więc w momencie, w którym odsuwamy pytania na temat „istoty” badanego obiektu i zadajemy pytania o sposób obserwacji tego, co obserwujemy ${ }^{12}$.

Jednocześnie powinienem pamiętać, że w perspektywie konstruktywistycznej nie mogę rościć sobie prawa do uznania tego, że moje poznawanie traktatu Sarbiewskiego jako traktatu narratologicznego jest jedynym możliwym sposobem jego interpretacji, ponieważ konstruktywizm - będąc kierunkiem zakładającym pragmatyczną i konsensualną koncepcję prawdy - odrzuca możliwość dotarcia do fundamentalnej istoty badanej rzeczy. Poznanie dzieła literackiego w myśl konstruktywizmu - twierdzi Siegfried J. Schmidt - jest bowiem z konieczności uzależnione od poznającego podmiotu, a obiektywność oraz intersubiektywność nauki nie wynika z jej adekwatności wobec realności, lecz stanowi produkt kulturowej zgody naukowców, „którzy przyjęli określone konstrukcje pojęciowe jako obowiązujące naukowo kategorie poznania"13.

Równie dobrze ktoś mógłby więc odczytać De perfecta poesi w porównaniu z siedemnastowiecznymi lirykami horacjańskimi albo konceptualizować ten traktat jako przykład antropologicznej koncepcji poetyckiego procesu twórczego. Przy czym warto wspomnieć, że wydźwięk antropologiczny refleksji teoretycznoliterackiej Sarbiewskiego w istotny sposób odróżnia jego poetykę od nieantropocentrycznych aspiracji strukturalistycznej nauki o opowiadaniu. W tej optyce pytanie, czy moja interpretacja dzieła De perfecta poesi jako dzieła narratologicznego jest prawdziwa czy fałszywa, musi zostać zweryfikowane jako niefortunnie sformułowane, „albowiem nawet tezy samego konstruktywizmu należy pojmować w ramach porządku wynalazku, a nie w ramach porządku odkrycia" ${ }^{14}$. W tym aspekcie konstruktywizm zbliża się do dekonstrukcji, zwłaszcza ze względu na tezę o nieobecności sensu, lub przynajmniej o niehegemonicznej roli tekstu jako strażnika głoszonych o nim twierdzeń interpretacyjnych.

Przedstawiłem pokrótce przedmiot mojego zainteresowania i sposoby obchodzenia się z tym przedmiotem. Wspomniałem też o samym konstruktywizmie, którego charakterystykę w perspektywie problemów poznawania tekstu dawnego trzeba jednak nieco rozwinąć. Przy czym należy dobitnie podkreślić, że nie ma jednolitego nurtu intelektualnego

11 L. Fleck, op. cit., s. 120.

12 Zob. A. Skrendo, op. cit., s. 68, przyp. 10.

13 S. J. Schmidt, Od tekstu do systemu. Zarys konstruktywistycznego (empirycznego) modelu nauki o literaturze, [w:] Konstruktywizm w badaniach literackich. Antologia, red. E. Kuźma, A. Skrendo, J. Madejski, Kraków 2006, s. 205.

14 A. Skrendo, op. cit., s. 68. 
o nazwie „konstruktywizm”, niemniej wspólny mianownik dla różnych odmian konstruktywistycznego myślenia polega na twierdzeniu, że wiedza nie dotyczy świata obiektywnego i poznawalnego w pełni, lecz konstruktów wytworzonych przez umysły ludzkie w procesach środowiskowej adaptacji - a zatem wiedza o świecie literatury (i wszystkie jego opisy) nie stanowi w konstruktywizmie odzwierciedlenia faktycznego (czy też „prawdziwego”) stanu rzeczy, lecz jest pożytecznym narzędziem przystosowania się umysłu ludzkiego do oporu, jaki stawia rzeczywistość ${ }^{15}$.

Na potrzeby swoich rozważań przyjmuję konstruktywistyczny model poznania ${ }^{16}$, który uwzględnia: 1) społeczne uwikłanie w wynajdywanie wiedzy, a nie jej neutralne odkrywanie; 2) nieistnienie faktów samych w sobie, czyli takich, które byłyby w jakimkolwiek ostatecznym dla nas sensie niepodważalne ${ }^{17}$; 3) przekonanie, że fakty naukowe powstają we wspólnocie stylu myślowego, polegającego na właściwym tylko tej wspólnocie trybie obserwacji przedmiotu, wypowiadania się o nim w określony sposób, a także przypisywania mu pewnych uzgodnionych właściwości przy pomocy wspólnych narzędzi poznawczych ${ }^{18}$; np. za pośrednictwem strukturalistycznych kategorii funkcji fabularnych jako narzędzi porównawczych w interpretacji dzieła De perfecta poesi.

Konstruktywistyczny model daje się zobrazować za pomocą ogólnego opisania procesu ludzkiego postrzegania kolorów przez ośrodkowy układ nerwowy. W książce On Constructivist Epistemology Thomas Rockmore pisze bowiem:

Wszystkie postrzeżeniowe fenomeny są „skonstruowane”. Wiemy, że barwy, które postrzegamy, nie istnieją dla nas bezpośrednio w oglądanym przez nas obiekcie, są one bowiem produktem procesu przetwarzania długości fal światła padających na siatkówkę oka, które następnie podróżują do nerwu optycznego, gdzie dopiero są przekładane na fenomeny wizualne ${ }^{19}$.

To, że potrafimy orzec o czymś z asercją, że jest koloru czerwonego, możemy uczynić tylko ze względu na to, iż nasze receptory przesłały do mózgu określone sygnały, które zostały następnie przetworzone w zamkniętym (odseparowanym od obserwowanego przez podmiot środowiska) systemie neuronalnym, czyli w mózgu. Innymi słowy, zarówno barwy, jak i wszystkie empiryczne fenomeny postrzeżeniowe nigdy nie mówią bezpośrednio same za siebie, a my nie znajdujemy się wewnątrz poznawanej przez nas rzeczywistości, lecz jesteśmy zdystansowanymi wobec niej obserwatorami, którzy spoglądają na owe fenomeny postrzeżeniowe niejako z zewnątrz, co sprawia, iż w pewnym sensie sytuujemy się poza bezpośrednio postrzegalnym przez nas światem. Jak zatem przekłada się ten model mentalny na poznawanie tekstu dawnego?

Otóż, tekst dawny, podobnie jak percypowany przez człowieka kolor, jest wynikiem działań w historycznych systemach komunikacyjnych, do których jako historycy literatury dawnej - zupełnie jak do obiektywnego świata fenomenów empirycznych - nie posiadamy bezpośredniego dostępu, innymi słowy: nie mamy wglądu w wiele sytuacji, które mogły w taki czy inny sposób wpłynąć na kształtowanie się np. procesu estetycznego, jakim jest

15 E. Kuźma, Wstęp, [w:] Konstruktywizm w badaniach literackich, s. 3

16 Zob. A. Zybertowicz, Przemoc i poznanie. Studium z nie-klasycznej socjologii wiedzy, Toruń 1995, s. $108-157$.

17 Ibidem, s. 59-113.

18 Ibidem, s. 108-109.

19 R. Hanna, On Constructivist Epistemology by Thomas Rockmore, "The Review of Metaphysics" 2008, No. 3, s. 660. Cytat przywołuję według tłumaczenia własnego. 
tworzenie literatury, pisanie dzieła literackiego. W modelu poznawczym literatury dawnej odpowiadają owe fenomeny wszystkim tym zjawiskom, do których (poprzez dystans czasowy) nie mamy jako współcześni badacze bezpośredniego dostępu. Możemy zatem obserwować jedynie opisy tych procesów pozostawione w tekście ${ }^{20}$. W przypadku dzieł dawnych ślady te nie muszą być rezultatem tylko sprawczości autora jako jedynego podmiotu odpowiedzialnego za ukształtowanie się dzieła, ponieważ (zwłaszcza w wypadku artefaktów piśmiennictwa krążących w manuskryptach i odpisach) zdeterminowane są te ślady komunikacyjnymi i społeczno-materialnymi losami najróżniejszych transformacji tekstu.

Ewa Bińczyk twierdzi bowiem, że między poszczególnymi etapami poznawczymi, między tym, co posiadamy na wejściu, i tym, co możemy uzyskać na wyjściu - nie zachodzi relacja determinacji ${ }^{21}$. Między punktem A (momentem wejścia tekstu dawnego w obieg komunikacyjny) a punktem B (chwilą aktualnego jego poznawania) powstaje tzw. czarna skrzynka, rozumiana jako przestrzeń fenomenów niedostępnych bezpośredniemu poznaniu. Siegfried J. Schmidt (jeden z fundatorów konstruktywistycznej nauki o literaturze) pisze, że

obszarem referencji konceptu „literatura” nie jest (zawarta w kanonie) ilość dzieł literackich, lecz społeczne operacje $[. .$.$] na fenomenach, które w komunikacji są tematyzowane jako feno-$ meny literackie. $\mathrm{O}$ ich literackości i jej literackiej randze nie decyduje wyizolowany tekst i jego pozornie obiektywne właściwości, lecz „komunikacyjne losy” tekstu literackiego w systemie literatury: literatura bowiem nie mówi sama za siebie!22

Wszelkie działania w systemie literatury, składające się na komunikacyjne losy tekstu, mogą być bowiem

realizowane $\mathrm{w}$ ramach czterech ról: producenta [Produzent] (produkującego postrzegalne rezultaty), pośrednika [Vermittler] (dystrybuującego produkty), odbiorcy [Rezipient] (akceptującego produkty innych aktantów i używającego ich do własnych działań) i przetwórcy [Verarbeiter] (produkującego produkt stanowiący odniesienie do produktu pierwotnego w sposób rozpoznawalny dla innych aktantów) ${ }^{23}$.

Wypada więc w tej optyce podkreślić, że traktat De perfecta poesi Sarbiewskiego był już pewną konstrukcją, zanim stał się tekstem w materialnym (i ukonstytuowanym fizycznie) tego słowa znaczeniu - istniał bowiem w sposób potencjalny w tym, co Andrzej Dąbrówka określa jako sermo in mente, a zatem w „mowie w myślach”24. Można powiedzieć, że sposób istnienia traktatu $O$ poezji doskonatej jako sermo in mente - jego stan wejściowy - posiadał niektóre cechy późniejszego tekstu (np. redakcji z XVIII wieku), lecz różnił się być może od wersji, którą znamy dzisiaj. Stanem wyjściowym jest bowiem dwujęzyczna (łacińsko-polska, drukowana i pozbawiona intertekstualnych marginaliów rękopisu) drukowana edycja

\footnotetext{
20 D. Ulicka, Zwrot archiwalny (jak ja go widzę), „,Teksty Drugie" 2010, nr 1/2, s. 162.

21 E. Bińczyk, Technonauka w społeczeństwie ryzyka: filozofia wobec niepożądanych następstw praktycznego sukcesu nauki, Toruń 2012, s. 105.

22 S. J. Schmidt, Literaturoznawstwo jako projekt interdyscyplinarny , "Teksty Drugie" 2010, nr 4, s. 153.

23 B. Balicki, Empiryczna Nauka o Literaturze - kierunek w badaniach literackich i szkoła naukowa, ,Teksty Drugie” 2010, nr 4, s. 40.

24 A. Dąbrówka, Konstruktywizm w badaniach literatury dawnej, „Nauka” 2009, nr 3, s. 137.
} 
dzieła De perfecta poesi. W perspektywie konstruktywistycznej wypada więc zadać pytanie, czy można bezkrytycznie zaufać współczesnym Tłumaczom i Edytorom dzieła staropolskiego, że udostępniony przedmiot badań jest rzeczywiście tym, czym był pierwotnie w zamyśle Sarbiewskiego?

Spod ręki Sarbiewskiego wyszedł tekst w języku obcym, który został przetłumaczony w całości na język polski dopiero w roku 1954. Nieścisłość, jaka zaistniała wokół tego tłumaczenia, stała się przedmiotem krytyki w artykule Sarbiewski jako krytyk Todorova, w którym Jerzy Ziomek wskazał merytoryczne niekonsekwencje w polskim tłumaczeniu specjalistycznych łacińskich pojęć z dziedziny genologii retorycznej ${ }^{25}$. Nie ma teraz miejsca na szczególowe opisywanie różnic między terminami historia, argumentum i fabula ${ }^{26}$. W perspektywie konstruktywistycznej wystarczy chyba podkreślić, że przekładanie tekstu jest już zawsze jego interpretowaniem ${ }^{27}$, a sens tekstu zależy nie tylko od samej czynności tłumaczenia dzieła z jednego kodu na inny, lecz również od przyjętej strategii translacyjnej ${ }^{28} \mathrm{i}$ od praktykowanego w danej zbiorowości stylu myślowego.

Konstruowanie tekstu to nie tylko produkcja (czyli autorstwo, redakcja i edycja), ale także - a niekiedy przede wszystkim - jego późniejsze przetwarzanie. W odniesieniu do dzieła De perfecta poesi historia przetwarzania rozpoczyna się w katedrze kolegium jezuickiego w Połocku, w którym polski preceptor poezji wykładał poetykę i retorykę. Pierwszym działającym aktorem, jaki uczestniczył w transformowaniu wiedzy Sarbiewskiego o klasycznej teorii poezji, był - jak twierdzą autorzy Przedmowy do O poezji doskonatej - prawdopodobnie anonimowy zastępca Sarbiewskiego na katedrze, który stał się później autorem podręcznika pod tytułem Poetica practica anno Domini 1648, opierającego się na ustaleniach teoretycznych zawartych w De perfecta poesi. Autor tej książki „wielokrotnie czerpał przykłady z Sarbiewskiego”, „niektóre partie prawie dosłownie odpisał od swego wielkiego poprzednika" ${ }^{29}$. Istnieje również prawdopodobieństwo, że pewne części tego podręcznika mogły być podyktowane przez samego Sarbiewskiego ${ }^{30}$. Nie możemy mieć także stuprocentowej pewności, że niektóre partie tekstu nie powstawały jako dyktowane po polsku, a dopiero później zostały przetłumaczone i spisane w języku łacińskim.

Jak twierdzą autorzy Przedmowy, przetwarzaniem ocalałych rękopisów Sarbiewskiego zajmował się na początku XVIII wieku niejaki Jan van der Ketten, który wydał pisma jezuickiego preceptora poezji w trzech częściach. Zawartość treściowa części pierwszej (o poezji epickiej) stała się przedmiotem analizy literackiego czasopisma jezuitów z 1717 roku. Według autorów tego czasopisma na twórczość teoretycznoliteracką Sarbiewskiego składało się podówczas dziewięć ksiąg ( w tym jedna księga De perfecta poesi, której tytuł nadano w procesie współczesnej redakcji). Natomiast w przypadku zbiorów van der Kettena mowa była tylko o trzech częściach poetyki i to bez podziału na poszczególne księgi.

Współczesna wersja dzieła poetologicznego Sarbiewskiego to więc swoiste ukoronowanie wielu złożonych działań archiwalnych i zarazem świadectwo sprawności nowo-

25 J. Ziomek, Sarbiewski jako krytyk Todorova, „Teksty” 1978, z. 2.

26 Zrobiłem to już jednak w innym miejscu. Zob. Ł. Lipiński, op. cit.

27 A. F. Kola, Wszyscy jesteśmy komparatystami, „Teksty Drugie” 2014, nr 4, s. 181.

28 M. Kaczorowska, Niezbędnik translatologiczny ,,"Teksty Drugie" 2003, nr 5, s. 109.

29 E. Sarnowska-Temeriusz, Poetyka M. K. Sarbiewskiego i G. J. Vossiusa, [w:] eadem, Zarys dziejów poetyki, Warszawa 1984, s. 520

30 Przedmowa, [w:] M. K. Sarbiewski, op. cit., s. XXXIV. 
czesnego warsztatu filologicznego, lecz także dowód przymusu rekonstrukcji faktów już na poziomie tytułu, a nie jedynie odczytywanie gotowego już tekstu, który - jak już była mowa za Schmidtem - nigdy nie „mówi sam za siebie”. Jak twierdzi Danuta Ulicka w pracy o „zwrocie archiwalnym” w badaniach literackich: „aby chwycić w ręce fakty, trzeba umieć je znaleźć - faktów samych w sobie jednak nie ma, także tych archiwalnych. Stwarza je dopiero filolog w towarzyszącym pracy edytorskiej gatunku komentarza”31.

$\mathrm{W}$ tej perspektywie wyczerpujące poznanie tekstu dawnego, w którym docieramy do totalnego jego sensu (uwzględniającego wszystkie procesy komunikacyjne, w jakich tekst uczestniczy1), jest niedostępne ze względu na dyseminacyjny i mgławicowy charakter tekstu. Przedmiot taki nie posiada bowiem żadnego zbiorczego centrum, np. w postaci „edycji kompletnej”, jaka mogłaby zawierać wszystkie treści (początkowe i końcowe) rozproszone dotychczas (przez stulecia) w poszczególnych rękopisach, odpisach, kopiach i komentarzach $^{32}$. Nie sposób też nie zgodzić się z Justyną Dąbkowską, która w artykule O edycji dziet dawnych $w$ serii „Biblioteka pisarzy staropolskich”33 pisze, że „spuścizna literacka twórców staropolskich już w czasach im współczesnych była rozproszona i nieuporządkowana, w dużej mierze za ich przyzwoleniem [... ]. Nie zawsze jednak o fakcie, iż dzieło zostało za życia pisarza opublikowane decydował on sam, będąc cenzorem i stróżem swojego dorobku"34. Bardzo często bowiem było tak, że dzieło krążyło w manuskryptach, notatkach i odpisach, a finalna wersja tekstu, z którym mamy możliwość obcować jako współcześni czytelnicy, jest nowożytną syntezą różnych (i różnej jakości) źródel, przetworzonych w procesach produkcji, pośredniczenia, odbioru i przetwarzania.

Interesujących informacji na temat losów rękopisów Sarbiewskiego dostarczają dwa dostępne dziś w formie muzealnej manuskrypty, które dwudziestowieczny wydawca oznaczył jako A i B. Rękopis A wydaje się „zasobniejszy”, natomiast B ma dużo „ciekawszą przeszłość”: posiada m.in. notatki sporządzone odmiennym charakterem pisma i bledszego koloru atramentem niż główny tekst rękopisu, a także inne niedatowane dopiski różnych autorów ${ }^{35}$. Śladów tych jednak nie znajdziemy w drukowanej wersji traktatu. Potwierdza się zatem teza, że „między poszczególnymi krokami, między tym, co mamy na wejściu i tym, co uzyskamy na wyjściu - nie zachodzi ścisła relacja determinacji”36 ${ }^{13}$ tej perspektywie nie można nie zgodzić się z twierdzeniem Andrzeja Dąbrówki, który w pracy Konstruktywizm $w$ badaniach literatury dawnej pisze, że

To, co dociera do nas jako utwór [a więc jako tekst - Ł. L.], dzieło poddawane obserwacji, jest $[\ldots] \mathrm{w}$ istocie płynnym wynikiem przetwarzania danych, raczej ciekłym stopem $\mathrm{w}$ formie niż gotowym odlewem, i to badacz tę formę musi podstawić, aby uzyskać jakiś odlew ${ }^{37}$.

\footnotetext{
31 D. Ulicka, op. cit., s. 162.

32 Niemniej taką możliwość oferuje koncepcja „Rękopisu 4D”. Zob. M. Troszyński, Rękopis 4D, "Teksty Drugie” 2014, nr 4.

${ }_{33}$ W tej edycji ukazały się traktaty Sarbiewskiego, w tym rozprawa De perfecta poesi.

34 J. Dąbkowska, O edycjach dzieł dawnych w serii „Biblioteka pisarzy staropolskich", "Teksty Drugie” 2003, nr 1, s. 101.

35 Przedmowa, [w:] M. K. Sarbiewski, op. cit., s. xxxvi i n.

36 E. Bińczyk, op. cit., s. 105.

37 A. Dąbrówka, op. cit., s. 134.
} 
Zapis, który dociera do współczesnego odbiorcy po długim czasie przetwarzania - pisze autor artykułu - jest najczęściej tylko śladem „rozległych i długotrwałych praktyk wykonawczych, a kształt zapisu rzadko odpowiada oryginałowi, zazwyczaj jest to nowożytna konstrukcja, wypracowana przez pokolenia filologów"38.

W optyce konstruktywistycznej należy więc pamiętać, że tekst jest wielością swoich różnorodnych postaci, które zostały rozproszone w wielu miejscach (archiwach, bibliotekach, zbiorach prywatnych itd.). W rezultacie powinno się używać liczby mnogiej (nie „tekst”, lecz „teksty”), ponieważ zwłaszcza w przypadku dzieł dawnych mamy do czynienia nie $\mathrm{z}$ jednym tekstem, ale po prostu $\mathrm{z}$ wieloma różnymi jego formami. Zapisy owe istnieją zatem jako materialna mnogość w sieci palimpsestowych zapośredniczeń o charakterze wewnątrz- oraz intertekstualnym, zarówno w rękopisach, jak i tam, gdzie znajdziemy do nich nawiązania. Nie mają one jednego autora, co z kolei utrudnia domknięcie procesu poznawczego wobec takiego przedmiotu badań. Wypada więc podkreślić, że forma czasownikowa „poznawanie” pojawiła się w tytule nie bez powodu. Konstruktywistyczne poznawanie tekstu dawnego - jak sama nazwa poniekąd wskazuje - ma bowiem charakter otwarty i procesualny, a to głównie ze względu na heterogeniczną naturę badanego tekstu. Finalny punkt kompletnego oglądu, w którym badacz dociera do kresu sensotwórczych możliwości tekstu, staje się w przypadku zapisu dawnego teoretycznie niedostępny. To właśnie dlatego konstruktywistyczne poznawanie tekstu dawnego zostało zakomunikowane w temacie artykułu za pomocą formy niedokonanej.

\section{Bibliografia}

Balicki Bogdan, Empiryczna Nauka o Literaturze - kierunek w badaniach literackich i szkoła naukowa, „Teksty Drugie” 2010, nr 4.

Barthes Roland, Wstęp do analizy strukturalnej opowiadań, przeł. W. Błońska, „Pamiętnik Literacki” 1968, z. 4.

Bińczyk Ewa, Technonauka w spoleczeństwie ryzyka: filozofia wobec niepożądanych następstw praktycznego sukcesu nauki, Toruń: Wydawnictwo UMK, 2012.

Bloomfield Harold Morton, Alegoria jako interpretacja, przeł. Z. Łapiński, „Pamiętnik Literacki” 1975, z. 3.

Dąbkowska Justyna, O edycjach dzieł dawnych w serii „Biblioteka pisarzy staropolskich”, „Teksty Drugie” 2003, nr 1.

Dąbrówka Andrzej, Konstruktywizm w badaniach literatury dawnej, „Nauka” 2009, nr 3.

Derrida Jacques, Pismo i różnica, przeł. K. Kłosiński, Warszawa: KR, 2004.

Fleck Ludwik, Style myślowe i fakty: artykuly i świadectwa, red. S. Werner, C. Zittel, F. Schmaltz, Warszawa: Wydawnictwo Instytutu Filozofii i Socjologii PAN, 2007.

Hanna Robert, On Constructivist Epistemology by Thomas Rockmore, „The Review of Metaphysics” 2008, No. 3.

Kaczorowska Marta, Niezbędnik translatologiczny, „Teksty Drugie” 2003, nr 5.

Kola Adam Franciszek, Wszyscy jesteśmy komparatystami, „Teksty Drugie” 2014, nr 4.

Konstruktywizm w badaniach literackich. Antologia, red. E. Kuźma, A. Skrendo, J. Madejski, Kraków: Universitas, 2006.

38 Ibidem, s. 140. 
Lipiński Łukasz, „De perfecta poesi” Macieja Kazimierza Sarbiewskiego w perspektywie wspótczesnych teorii narracji, „Meluzyna” 2014, nr 1.

Nietzsche Fryderyk, Poza dobrem i złem, przeł. S. Wyrzykowski, Warszawa: vis-a-vis/Etiuda, 2015.

Sarbiewski Maciej Kazimierz, De perfecta poesi, sive Vergilius et Homerus (O poezji doskonatej, czyli Wergiliusz i Homer), przeł. M. Plezia, oprac. S. Skimina, Wrocław: Zakład Narodowy im. Ossolińskich, 1954.

Sarnowska-Temeriusz Ewa, Zarys dziejów poetyki (od starożytności do końca XVII w.), Warszawa: Państwowe Wydawnictwo Naukowe, 1984.

Schmidt Siegfried Johannes, Literaturoznawstwo jako projekt interdyscyplinarny, „Teksty Drugie” 2010, nr 4.

Skrendo Andrzej, Tożsamość w perspektywie konstruktywizmu, „Teksty Drugie” 2004, nr 1/2.

Troszyński Marek, Rękopis 4D, „Teksty Drugie” 2014, nr 4.

Ulicka Danuta, Zwrot archiwalny (jak ja go widze), „Teksty Drugie” 2010, nr 1/2.

Ziomek Jerzy, Sarbiewski jako krytyk Todorova, „Teksty” 1978, z. 2.

Zybertowicz Andrzej, Przemoc i poznanie. Studium z nie-klasycznej socjologii wiedzy, Toruń: Wydawnictwo UMK, 1995. 